\title{
Effect of different concentration of intraumblical injection of oxytocin and saline on third stage of labor
}

\begin{abstract}
Objectives: The aim of study is to study the different concentration of intraumblical oxytocin saline injection on duration and blood loss of third stage of labor and other parameter.

Methods: After considering inclusion and exclusion criteria, cases were divided in to 5 groups. All Women were injected $50 \mathrm{ml}$ of normal saline into umbilical vein immediately after clamping and cutting the cord, in group A without oxytocin, in Group B with 10 units of oxytocin, in group C with 20 unit oxytocin and in group D with 30 unit oxytocin. In group E (control) women were managed conservatively. Duration and amount of blood loss of third stage was noted.

Results: There were total 250 women enrolled in the study. A statistically significant reduction in the duration and amount of blood loss of third stage of labor was found in group B compared to group A. On increasing the concentration of oxytocin from $10 \mathrm{IU}$ to $20 \mathrm{IU}$ a slight reduction in mean duration and amount of blood loss of third stage was noted. On further increasing the concentration of oxytocin to $30 \mathrm{IU}$ a statistical significant reduction was present.
\end{abstract}

Conclusion: For active management of third stage intraumblical injection of oxytocin with saline should be promoted.

Keywords: Post partum, Hemorrhage, Oxytocin, Third stage of labour
Volume 4 Issue 4 - 2016

\author{
Zeepee Godha, Neeta Bindal, Dharma \\ Meena, Rashi \\ Department of Obstetrics and Gynaecology, Deen Dayal \\ Hospital, India
}

\begin{abstract}
Correspondence: Zeepee Godha, MS in Obs \& Gynae, Senior Resident in department of Obstetrics and Gynaecology at Deen Dayal Hospital, New Delhi, India, Tel 9I-7827485827,
\end{abstract}

Email zeepe_dr@yahoo.co.in

Received: March 24, 2016| Published: May 09, 2016

\section{Introduction}

Third stage of labor is defined as the duration of labor from the birth of the baby till the complete expulsion of the placenta and membranes. ${ }^{1}$ Post partum hemorrhage (PPH) is one of the most common and distressing complications encountered during this period, ${ }^{2}$ which can be life threatening also. In India it is one of the major causes of maternal mortality, accounting for $29.6 \%$ of maternal mortality. ${ }^{3}$ According to WHO it is defined as blood loss of $500 \mathrm{ml}$ or more from genital tract following delivery in first 24 hours of delivery. ${ }^{4}$ In literature it is also defined as decrease in hematocrit level by $10 \%$ or more of its value before labor. ${ }^{5}$ Third stage can be managed by expectant management or active management. With active management the incidence of severe PPH (blood loss greater than $1000 \mathrm{ml}$ ) is around $5 \%$ and that of moderate PPH is $14 \%$ (blood loss $>500 \mathrm{ml}$ ) following vaginal delivery. ${ }^{6,7}$ Active management can prevent $60-70 \%$ of atonic PPH. ${ }^{8}$ So active management of third stage of labor has become the rule, to prevent maternal morbidity and mortality. ${ }^{9}$ Uterine atony is the most common cause of PPH..$^{10}$ Active management of third stage of labor include use of uterotonics, clamping of the umbilical cord once it stop pulsating, controlled traction of the cord and massage of the fundus of the uterus. ${ }^{11}$ Various uterotonics used in active management of third stage of labor are Oxytocin, methylergometrine and prostaglandins. Intraumblical injection of diluted oxytocin is one of the safe and effective uterotoinc. It causes direct early uterine contraction and separation of placenta and also hydraulic action of saline help placental separation by mechanical pressure. The aim of present study is to study the different concentration of intraumblical oxytocin saline injection on duration and blood loss of third stage of labor and other parameter.

\section{Material and methods}

The study was conducted in the department of obstetrics and gynaecology of Deen Dayal Upadhyay Hospital, New Delhi from February 2009 to February 2010. 250 pregnant women between 37 to 41 weeks were enrolled in the study after written and informed consent. Inclusion criteria were primigravida, second gravida with previous one abortion, spontaneous onset of labor and without any medical disease of pregnancy. Grand multipara women, pregnancy with antepartum hemorrhage, multiple pregnancy, chorioaminitis, severe anaemia, pregnancy requiring induction of labour and $\mathrm{Rh}$ negative pregnancy were excluded from the study. All cases were divided in to 5 groups.

a. Group A: Women were injected with $50 \mathrm{ml}$ of normal saline in umbilical vein immediately after clamping and cutting the cord.

b. Group B: Women were injected with 10 units of oxytocin in 50 $\mathrm{ml}$ of normal saline in umbilical vein immediately after clamping and cutting the cord.

c. Group C: Women were injected with 20 units of oxytocin in 50 $\mathrm{ml}$ of normal saline in umbilical vein immediately after clamping and cutting the cord.

d. Group D: Women were injected with 30 units of oxytocin in 50 $\mathrm{ml}$ of normal saline in umbilical vein immediately after clamping and cutting the cord.

e. Group E (control): Women were managed conservatively during third stage of labor 
Placenta was delivered by modified Brandt Andrews method following appearance of signs and symptoms of placental separation. Total duration of third stage of labor was recorded in all cases. To assess the blood loss a kidney tray of $200 \mathrm{ml}$ capacity containing Ethylene Diamine Trichloracetic acid (EDTA) $1.2 \mathrm{mg} / \mathrm{ml}$ was held firmly against the perineum and blood lost in third stage of labor was allowed to collect in this tray. The pad of similar absorbant capacity (10 gm weight by spring balance) were used for moping. All the pads used for moping were collected in the end. The difference between weigh before and after use was measured and noted. Total amount of blood loss was calculated by adding blood loss from kidney tray and pad soakage. Placenta was examined for its completeness, diameter, weight and cord length. Any abnormality of placenta like circumvallate placenta or any calcification was noted. The birth weight of baby was noted. Total time elapsed from intraumblical injection to the delivery of placenta were noted. Patients with instrumental delivery were excluded from the study. Any complication during the third stage of labour like postpartum haemorrhage, retained placenta or any side effects of oxytocin were noted. Hemoglobin and hematocrit before and after 24 hours of delivery were checked. Statistical analysis was done by applying ANOVA test.

\section{Results}

There was total 250 women enrolled in the study. Mean age of women was 21.79 years. Mean duration of first stage of labour was comparable in all groups (Table 1). No statistical difference was present in mean duration of second stage between all groups. A statistically significant reduction in duration of third stage of labour was present in all other groups compared with control group managed conservatively. A statistically significant reduction in the duration of third stage of labor was found in group B managed with $50 \mathrm{ml}$ intraumblical saline with 10 units oxytocin compared to group A managed with $50 \mathrm{ml}$ saline alone. On increasing the concentration of oxytocin from 10 IU to 20 IU a slight reduction in mean duration of third stage was noted which was not statistically significant. On further increasing the concentration of oxytocin to $30 \mathrm{IU}$ a statistical significant reduction in third stage duration was present.

The changes in the mean amount blood loss in third stage of labour followed the same trend as that of the mean duration of third stage with intraumblical injection of saline with or without oxytocin (Table 1). A statistically significant lower blood loss was present in all other group than control group. Statistically significant reduction in blood loss was present in group B than group A. No difference was found between amount of blood loss in third stage between group B and $\mathrm{C}$ while statistically significant reduction was observed in amount of blood loss in group D than group C.

Table 2 The difference in predelivery and postdelivery hemoglobin and hematocrit was maximum in the control group managed conservstively. The difference in predelivery and postdelivery hemoglobin and hematocrit was statistically less in all the study groups compared to control group. Statistically significant less difference in predelivery and postdelivery hemoglobin and hematocrit was present in group B than group A. No statistically significant difference was found between group B and C while statistically significant reduction was observed in pre and post delivery loss in group D than group C.

Table I Duration of labor in all stages and mean amount of blood loss in third stage

\begin{tabular}{|c|c|c|c|c|c|}
\hline $\begin{array}{l}\text { Duration of } \\
\text { labour }\end{array}$ & Group A & Group B & Group C & Group D & Group E \\
\hline $\begin{array}{l}\text { Stage I st }(\mathrm{hr}) \\
\text { Range }\end{array}$ & $\begin{array}{l}12.42 \\
(10.50-15.00)\end{array}$ & $\begin{array}{l}12.38 \\
(10.33-15.33)\end{array}$ & $\begin{array}{l}12.22 \\
(10.00-15.00)\end{array}$ & $\begin{array}{l}12.79 \\
(10.00-15.00)\end{array}$ & $\begin{array}{l}12.29 \\
(10.67-14.00)\end{array}$ \\
\hline $\begin{array}{l}\text { Stage } 2^{\text {nd }}(\mathrm{hr}) \\
\text { Range }\end{array}$ & $\begin{array}{l}\mathrm{I} .07 \\
(.25-1.82)\end{array}$ & $\begin{array}{l}1.18 \\
(0.75-1.58)\end{array}$ & $\begin{array}{l}\text { I.23 } \\
(0.25-2.00)\end{array}$ & $\begin{array}{l}\text { I. } 18 \\
(0.25-1.82)\end{array}$ & $\begin{array}{l}\text { I.04 } \\
(0.25-2.00)\end{array}$ \\
\hline $\begin{array}{l}\text { Stage } 3^{\text {rd }}(\min ) \\
\text { Range }\end{array}$ & $\begin{array}{l}2.46 \\
(2.32-2.59)\end{array}$ & $\begin{array}{l}1.85 \\
(1.56-2.13)\end{array}$ & $\begin{array}{l}1.83 \\
(1.33-2.34)\end{array}$ & $\begin{array}{l}\text { I..25 } \\
(0.5|-2.3|)\end{array}$ & $\begin{array}{l}2.79 \\
(2.09-3.49)\end{array}$ \\
\hline $\begin{array}{l}\text { Mean blood loss in } \\
3^{\text {rd }} \text { stage \& range }\end{array}$ & $\begin{array}{l}193 \mathrm{ml} \\
170-210\end{array}$ & $\begin{array}{l}\mid 48 \\
|20-| 80\end{array}$ & $\begin{array}{l}142.20 \\
50-195\end{array}$ & $\begin{array}{l}96.68 \\
60-130\end{array}$ & $\begin{array}{l}218.4 \\
180-450\end{array}$ \\
\hline
\end{tabular}

Table 2 Difference in pre and post delivery hemoglobin and hematocrit value in all groups

\begin{tabular}{|c|c|c|c|c|c|}
\hline & Group A & Group B & Group C & Group D & Group E \\
\hline Predelivery Mean Hb gm \% & 11.17 & 11.33 & 11.17 & $1 \mathrm{I} .4 \mathrm{I}$ & 11.36 \\
\hline Mean Hematocrit\% & 36.86 & 37.38 & 36.86 & 37.65 & 37.48 \\
\hline Postdelivery Mean Hb gm\% & 9.96 & 10.26 & 10.09 & 10.46 & 10.08 \\
\hline Mean Hematocrit\% & 33.21 & 34.16 & 33.64 & 34.88 & 33.62 \\
\hline Difference of pre \& post delivery $\mathrm{Hb}$ & 1.21 & 1.07 & 1.08 & .95 & 1.28 \\
\hline Difference of pre \& post delivery hematocrit & 3.65 & 3.22 & 3.17 & 2.77 & 3.86 \\
\hline
\end{tabular}

Table 3 Mean birth weight of babies and placental characteristics of all groups

\begin{tabular}{llllll}
\hline & Group A & Group B & Group C & Group D & Group E \\
\hline Mean birth weight $(\mathrm{kg})$ & 2.68 & 2.67 & 2.64 & $2.6 \mathrm{I}$ & 17.80 \\
Mean diameter of placenta $(\mathrm{cm})$ & 17.50 & 17.60 & $17.7 \mathrm{I}$ & 17.52 & 476.00 \\
Mean weight of placenta $(\mathrm{gm})$ & 476.20 & 487.20 & 476.40 & 468.52 & 47.00 \\
\hline
\end{tabular}

There was no statistically significant difference present in pre delivery mean hemoglobin and hematocrit value of all groups. Table 2 shows the post delivery hemoglobin and hematocrit of all groups. There was no statistically significant difference present of post delivery hemoglobin and hematocrit value of between group $\mathrm{E}$ and group A and B. Statistically significant difference e noted between group $\mathrm{E}$ and group $\mathrm{C}$ and $\mathrm{D}$.

Mean birth weight of babies born was $2.65+/-.21 \mathrm{~kg}$. However no statistical significant difference was noted between various groups in mean birth weight of babies. The mean weight of placenta was 476 
$+/-57.86 \mathrm{gm}$. however no statistical significant difference was noted between various groups. The diameter of placenta of all groups ranged between $16-19 \mathrm{cms}$. However no statistical significant difference was noted between various groups Table 3 .

As shown in Table 4 that there is a positive correlation between the third stage duration and the third stage blood loss in all the groups individually. Thus implying that greater the third stage duration, the greater is the blood loss and vice versa.

\section{Discussion}

Post partum hemorrhage is the one of the most distressing complication for both clinician and patients. Its complications include maternal anemia, hypovolumic shock, acute renal failure, hepatic failure, coagulopathy, exposure to blood product, mortality. There are other studies done to compare the effect of intraumblical oxytocin with other uterotonic. (Table 5) Kore et al. ${ }^{12}$ found significant less blood loss and duration of third stage of labour with intraumblical injection of 10 units of oxytocin than 10 units of IV oxytocin. ${ }^{12}$ Manhas et al. ${ }^{13}$ also found significant less blood loss and duration of third stage of labour with intraumblical injection of 20 units of oxytocin than $2 \mathrm{mg}$ of methylergometrine IV. ${ }^{13}$ While Ojha et al. ${ }^{14}$ found almost no difference in duration of third stage of labour with intraumblical injection of 10 units of oxytocin than 10 units of IM oxytocin and blood loss in third stage was more with intraumblical oxytocin. ${ }^{14}$ But in their study the new born birth weight was more with intraumblical group than IM oxytocin $(3.025 \mathrm{~kg}$ vs $2.875 \mathrm{~kg})$ and one more reason was longer injection delivery interval with intraumblical oxytocin $(46.9 \mathrm{sec}$ vs $30.7 \mathrm{sec})$.

Table 4 Pearson's correlation between the blood loss and third stage duration in various group

\begin{tabular}{ll}
\hline Groups & Correlation \\
\hline Group A & $0.845(\mathrm{P}<0.00 \mathrm{I})$ \\
Group B & $0.965(\mathrm{P}<0.00 \mathrm{I})$ \\
Group C & $0.948(\mathrm{P}<0.00 \mathrm{I})$ \\
Group D & $0.995(\mathrm{P}<0.00 \mathrm{I})$ \\
Group E & $0.873(\mathrm{P}<0.00 \mathrm{I})$ \\
\hline
\end{tabular}

Table 5 Comparison of present study with other studies

\begin{tabular}{|c|c|c|c|}
\hline & Third stage mean duration (min) & Third stage blood loss (ml) & \\
\hline \multirow{2}{*}{ Kore et al. ${ }^{12}$} & $5.6 \pm 3.2$ & $125 \pm 30$ & 10 units of oxytocin $20 \mathrm{ml}$ saline $\mathrm{IU}$ \\
\hline & $10.2 \pm 2.8$ & $275 \pm 55$ & 10 units of oxytocin IV \\
\hline \multirow[t]{3}{*}{ Manhas et al. ${ }^{13}$} & $3.17 \pm 1.55$ & $107 \pm 13$ & 20units of oxytocin in $20 \mathrm{ml}$ of saline IU \\
\hline & $8.22 \pm 2$ & $195 \pm 33$ & $20 \mathrm{ml}$ of normal saline \\
\hline & $4.6 \pm 2$ & $113 \pm 15$ & $0.2 \mathrm{mg}$ of methylergometrine IV \\
\hline \multirow[t]{2}{*}{ Ojha et al. ${ }^{14}$} & $3.6 \pm 1.5$ & $96.2 \pm 79.2$ & 10 units of oxytocin in $10 \mathrm{ml}$ of saline $\mathrm{IU}$ \\
\hline & $3.7 \pm 1.3$ & $77.7 \pm 58.1$ & 10 units of oxytocin IM \\
\hline
\end{tabular}

In contrast to our study cochrane review found no difference in results of intraumblical vein injection of saline plus oxytocin compared with both intravenous and intramuscular injection of oxytocin. But they also mentioned that overall quality of trial was not good, because most of the studies included did not report all information required, number of trial included was also limited. Although routine use of intraumblical injection of oxytocin with saline is not recommended with this report but its selected use in patients who are having risk factor for post partum hemorrhage as in multigravida, polyhydraminos, twin pregnancy or in whom other uterotonic are contraindicated as in hypertensive, anemia intraumblical injection of oxytocin with saline is an effective option.

\section{Conclusion}

Intraumblical injection of diluted oxytocin is a effective measure in reducing the duration and blood loss in third stage of labor. We need large randomized trial to implement its use in active management of third stage of labor. But it can be safely use in high risk patients where more blood loss is anticipated.

\section{Acknowledgements}

None.

\section{Conflict of interest}

None.

\section{References}

1. Dutta DC. Textbook of Obstetrics. (3rd edn.), New Central book agency, Calcutta, India. 1992;pp.128-130.

2. Chamberlain G. The clinical aspects of massive haemorrhage. Maternal Mortality-The Way forward London: RCOG. 1992;54-62.

3. Kishore J. National Health programmes of India. (4th edn), Central Publications, New Delhi, India. 2001;p:27

4. WHO. The Prevention and Management of Postpartum Haemorrhage. Report of a Technical Working Group. Geneva 3-6 July 1989. World Health Organization/Maternal and Child Health 90.7. WHO, Geneva, Switzerland. 1990;p:1-36.

5. Combs CA, Murphy EL, Laros RK. Factors associated with PPH with vaginal birth. Obstet Gynecol. 1991;77(1):69-76.

6. Gulmezoglu AM, Villar J, Ngoc NT, et al. WHO multicentre randomised trial of misoprostol in the management of the third stage of labour. Lancet. 2001;358(9283):689-695.

7. Magann EF, Evans S, Chauhan SP, et al. The length of the third stage of labor and the risk of postpartum haemorrhage. Obstet Gynecol. 2005;105(2):290-293.

8. PK Sekharan. Prevention and prediction of postpartum haemorrhage. FOGSI FOCUS. 2007.

9. Prendiville WJ, Elbourne DR, Mc Donald S. Active versus expectant management of the third stage of labour. Cochrane Database Syst. 1996; $\operatorname{Rev}(3): C D 000007$. 
10. Mori R, Nardin JM, Yamamoto N, et al. A Umblical vein injection for the routine management of third stage of labour (review). Cochrane Database Syst. 2012;Rev3:CD006176.

11. M Patil. Active management of third stage of labor. Principles and practice of Obstetrics and Gynaecology for PG. A FOGSI Publications. $2008 ; 1: 351$.

12. Kore S, Srikrishna S, Hedge A, et al. Active management of third stage of labour with intraumbilical oxytocin injection. $J$ Obstet Gynaecol India. 2000;50(3):54-55.
13. Aranjana Manhas, Humma Habib, Syed Naseer, et al. A Randomized Controlled Study of Prophylactic Use of Umbilical Vein Oxytocin in The Management of Third Stage of Labor. IOSR Journal of Dental and Medical Sciences. 2012;1(6):27-30.

14. Ojha N, Malla DS. Active management of third stage of labour by oxytocin: Umbilical vein versus intramuscular use. Nepal Journal of Obstetrics and Gynaecology. 2007;2(1):13-16. 